\title{
RESISTENSI KOMUNITAS KRETEK DALAM MEMPERTAHANKAN KESEJAHTERAAN KRETEK DI INDONESIA
}

\author{
Sri Ruth Meilina Sianturi \\ Embassy English Centre
}

\begin{abstract}
ABSTRAK
Isu hangat Framework Convention of Tobacco Control (FCTC) yang masih belum disahkan di Indonesia memojokkan produktivitas tembakau dan kretek di Indonesia. Wanda Hamilton lewat bukunya Nicotine War mengungkapkan bahwa perang terhadap tembakau ini bukanlah semata karena isu kesehatan saja, namun juga terdapat kepentingan politik dan bisnis yang kuat. Eksistensi Komunitas Kretek ada untuk melawan dan mencegah pemusnahan kretek di Indonesia, karena selain merupakan komoditas terakhir pertanian Indonesia, kretek juga memiliki nilai sejarah dan budaya yang kental, serta untuk membela hak-hak pengkretek yang telah mengalami diskriminasi. Teori yang digunakan dalam penelitian ini ialah teori interaksi simbolik, teori dekonstruksi, teori konflik, dan model kampanye. Paradigma yang digunakan ialah paradigma kritis. Sedangkan metode penelitiannya ialah kualitatif dengan jenis penelitian studi kasus. Hasil penelitian yang diperoleh ialah: 1) Komunitas Kretek melakukan perlawanan terhadap ratifikasi FCTC; 2) Komunitas Kretek mempertahankan hak-hak pengkretek; 3) Komunitas Kretek mempertahankan kretek sebagai cagar budaya Indonesia. Kesimpulan yang penelitian ini ialah Komunitas Kretek melakukan resistensi untuk mempertahankan kemerdekaan kretek di Indonesia dengan melawan ratifikasi FCTC, merubah kebijakan yang dapat berakibat buruk terhadap keberlangsungan kretek di Indonesia, serta mempertahankan eksistensi kretek sebagai cagar budaya Indonesia.
\end{abstract}

Kata-kata Kunci: Resistensi, kretek, ratifikasi FCTC, komunitas kretek, cagar budaya Indonesia

\section{THE RESISTANCE OF KRETEKCOMMUNITY IN ORDER TO KEEP THE WELFARE OF KRETEK IN INDONESIA}

\begin{abstract}
The FCTC (Framework Convention of Tobacco Control) issue which has not been legalized in Indonesia creates as situation in which limit the productivity of tobacco and kretek in Indonesia. Wanda Hamilton, in her book, Nicotine War reveals that the war toward tobacco is not only because of the health issue, but also because of the strong political and business interests. The existence of Kretek community is to resist and prevent the vanishing of kretek in Indonesia, because kretek is not only the last commodity of Indonesia's agriculture but also has a deep historical and cultural value. The community also fights for the rights of kretek's consumers which have been discriminated. Theories used in this research are the symbolic interaction theory, the deconstruction theory, the conflict theory, and the campaign model. The paradigm used in this research is critical paradigm. The research method is qualitative with case study. The results are: 1) Kretek community do the resistance toward FCTC's ratification; 2) Kretek community covers the rights of kretek's; 3) Kretek community keep kretek as Indonesia's heritage. The conclusion from this research is Kretek community doing the resistance in order to keep the independence of kretek in Indonesia by opposing the FCTC's ratification, change of regulation that enabling loss of Kretek sustainability in Indonesia, and also keeping the existence of kretek as one of the Indonesia's heritages.
\end{abstract}

Keywords: Resistance, cigarettes, FCTC's ratification, cigarettes community, Indonesia's heritage

Korespondensi: Sri Ruth Meilina Sianturi, S.S., M.I.Kom. Embassy English Centre. The Terrace TT-09 Pakuwon Trade Centre, Jl. Puncak Indah Lontar No. 2 Surabaya 60216. Email: sriruthmeilina.sianturi@ yahoo.com 


\section{PENDAHULUAN}

Maraknya kampanye anti rokok dan anti tembakau mengakibatkan bulatnya pandangan masyarakat bahwa kretek merupakan hal yang berbahaya bagi kesehatan dan patut untuk dienyahkan dari Indonesia. Tak luput dengan kebijakan yang dibuat pemerintah serta isu hangat Framework Convention of Tobacco Control(FCTC) yang masih belum disahkan di Indonesia semakin memojokkan produktivitas tembakau dan kretek di Indonesia. Disahkannya FCTC di Indonesia akan merugikan banyak pihak. Terdapat temuan Wanda Hamilton lewat bukunya Nicotine War yang mengungkapkan bahwa perang terhadap tembakau ini bukanlah semata karena isu kesehatan saja, namun juga terdapat kepentingan politik dan bisnis yang kuat. Apalagi Indonesia memiliki kretek, produk asli Nusantara yang merupakan olahan tembakau dan cacahan cengkeh yang jika dibakar menghasilkan aroma yang khas dan berbunyi kretek-kretek. Eksistensi Komunitas Kretek ada untuk melawan dan mencegah pemusnahan kretek di Indonesia, karena selain merupakan komoditas terakhir pertanian Indonesia, kretek juga memiliki nilai sejarah dan budaya yang kental, serta untuk membela hak-hak pengkretek yang telah mengalami diskriminasi.

Herbert Mead, seorang tokoh pencetus iNteraksi simbolik, sangat mengagumi kemampuan manusia untuk menggunakan simbol dan ia menyatakan bahwa "orang bertindak berdasarkan makna simbolik yang muncul di dalam sebuah situasi tertentu". Senada dengan itu, Ralph Larossa dan Donald R. Reitzes menyumbang pemikiran terhadap teori ini. Menurut mereka, interaksi simbolik "pada intinya... sebuah kerangka referensi untuk memahami bagaimana manusia, bersama dengan orang lainnya menciptakan dunia simbolik dan bagaimana dunia ini, sebaliknya membentuk perilaku manusia" (West dan Turner, 2008: 96). Dari pemaparan ini terdapat sebuah hubungan yang tak dapat dipisahkan antara manusia sebagai individu dengan masyarakat. Individu merupakan partisipan aktif dan reflektif terhadap konteks sosialnya.

Di sisi lain, penelitian ini membutuhkan dekonstruksi. Dekonstruksi merupakan "sebuah tindakan dari subjek yang membongkar sebuah objek yang tersusun dari berbagai unsur"
(Norris, 2008: 5). Ialah Jacques Derrida, seorang filsuf Perancis kelahiran Aljazair tahun 1930 yang dikenal dengan metode dekonstruksinya.

Hal yang dicari dan diburu oleh manusia modern selama ini, yakni kepastian tunggal yang ada di depan, tidaklah ada. Tidak ada satupun yang bisa dijadikan pegangan, karena satu-satunya yang bisa dikatakan pasti adalah ketidakpastian. Semuanya harus ditangguhkan (deffered) sembari manusia terus bermain bebas dengan perbedan (to differ). Inilah yang ditawarkan Derrida dan posmodernitas, yakni permainan dengan ketidakpastian. Adapun yang khas dalam cara baca dekonstruktif, sehingga pada perjalanan selanjutnya dia sangat bermuatan filosofis, adalah bahwa unsur-unsur yang dilacaknya, untuk kemudian dibongkar, pertama-tama bukanlah inkonsistensi logis, argumen yang lemah, atau pun premis tidak akurat yang terdapat dalam teks, sebagaimana biasa dilakukan oleh pemikiran modernisme, melainkan unsur yang secara filosofis menjadi penentu yang memungkinkan teks tersebut menjadi filosofis. Kasarnya, kemungkinan filsafat itu sendirilah yang dipersoalkannya (Norris, 2008: 11). Dekonstruksi bermain di kekaburan batas yang sama, menangguhkan segala hal yang masyarakat terima sebagai taken for granted dari bahasa, pengalaman dan kemungkinan-kemungkinan lain dari komunikasi "normal" antarmanusia.

Selain interaksionisme simbolik dan dekonstruksi, teori lain yang tepat untuk mengeksplorasi fenomena ini adalah teori konflik. Teori konflik berangkat dari ranah ilmu sosiologi. Teori ini berkembang atas reaksi terhadap fungsionalisme struktural. Fungsionalisme struktural sendiri ialah sebuah teori yang berkutat tentang struktur masyarakat dan fungsinya. Teori konflik menekankan pada dominasi kelompok sosial tertentu oleh kelompok lain; melihat keteraturan sosial didasarkan atas manipulasi dan kontrol oleh kelompok dominan; dan memandang perubahan sosial terjadi secara cepat dan menurut cara yang tak teratur ketika kelompok-kelompok subordinat menggulingkan kelompok yang semula dominan (Ritzer dan Goodman, 2005: 116).

Terdapat konsep kunci lain dalam teori konflik yang Dahrendorf kemukakan, yakni kepentingan. Kelompok yang berada di atas dan yang berada di bawah didefinisikan berdasarkan 
kepentingan bersama. Dalam setiap asosiasi, orang yang berada pada posisi dominan berupaya mempertahankan status quo, sedangkan orang yang berada pada posisi subordinat berupaya mengadakan perubahan. Konflik kepentingan di dalam asosiasi selalu ada sepanjang waktu, setidaknya yang tersembunyi. Hal ini berarti legitimasi otoritas selalu terancam. Adapun konflik kepentingan ini tak selalu perlu disadari oleh para pelakunya, yakni pihak superordinat dan subordinat.

Ada banyak model kampanye yang ditawarkan oleh para ahli, namun model yang paling sesuai dengan kampanye yang dilakukan oleh Komunitas Kretek ialah model yang ditawarkan oleh Nowak dan Warneryd. Model kampanye ini termasuk dalam golongan model tradisional kampanye. Dalam model ini, kampanye dimulai dari proses membuat tujuan yang ingin dicapai dan diakhiri dengan efek yang diinginkan.Lebih jelasnya, model kampanye Nowak dan Warneryd dapat dilihat dalam bagan 1 .

Konsep terakhir yang digunakan dalam landasan teoretis penelitian ini ialah resistensi. Routledge (1997) mendefinisikan resistensi sebagai any action imbued with intent that attempts to challenge, change or retain particular circumstances relating to societal relations, processes and/or institutions... [which] imply some form of contestation... [and] cannot be separated from practices of domination.

Dalam pengertian sederhana, penulis mengartikan definisi resistensi di atas sebagai tindakan apa pun yang dijiwai dengan maksud untuk menantang, merubah atau pun mempertahankan suatu keadaan tertentu yang berhubungan dengan hubungan sosial, proses dan/atau sebuah institusi yang berimplikasi pada sebuah bentuk argumentasi yang panjang dan kuat, serta tak dapat dipisahkan dari praktik dominasi.

Berdasarkan paparan di atas, adapun tujuan dari penelitian ini ialah untuk mendeskripsikan dan mengeksplanasikan perlawanan yang dilakukan Komunitas Kretek terhadap ratifikasi FCTC; untuk mengeksplorasi tindakan Komunitas Kretek dalam melindungi hak-hak para pengkretek; dan untuk mengeksplorasi tindakan Komunitas Kretek dalam mempertahankan kretek sebagai salah satu cagar budaya Indonesia. Beberapa teori yang digunakan dalam penelitian ini ialah teori interaksi simbolik, teori dekonstruksi, teori konflik dan model kampanye. Konsep resistensi pun digunakan menjadi landasan teoritis di penelitian ini.

\section{METODE PENELITIAN}

Menilik tema yang diusung dalam penelitian ini ialah resistensi, maka metode penelitian yang tepat guna ialah kualitatif dan paradigma yang menjadi payung penelitian ialah paradigma kritis. Paradigma kritis menerima asumsiasumsi dasar tertentu, seperti yang dikutip dalam Handbook of Qualitative Research, bahwa (1) Seluruh pemikiran secara fundamental dimediasi oleh relasi-relasi kekuasaan yang dibentuk secara sosial dan kesejarahan; (2) Fakta-fakta tidak pernah bisa dilepaskan dari domain nilai atau dibebaskan dari bentuk inkripsi ideologis tertentu; (3) Hubungan antara konsep dan antara penanda dengan petanda (yang ditandai) tidak pernah stabil, dan sering kali dimediasi

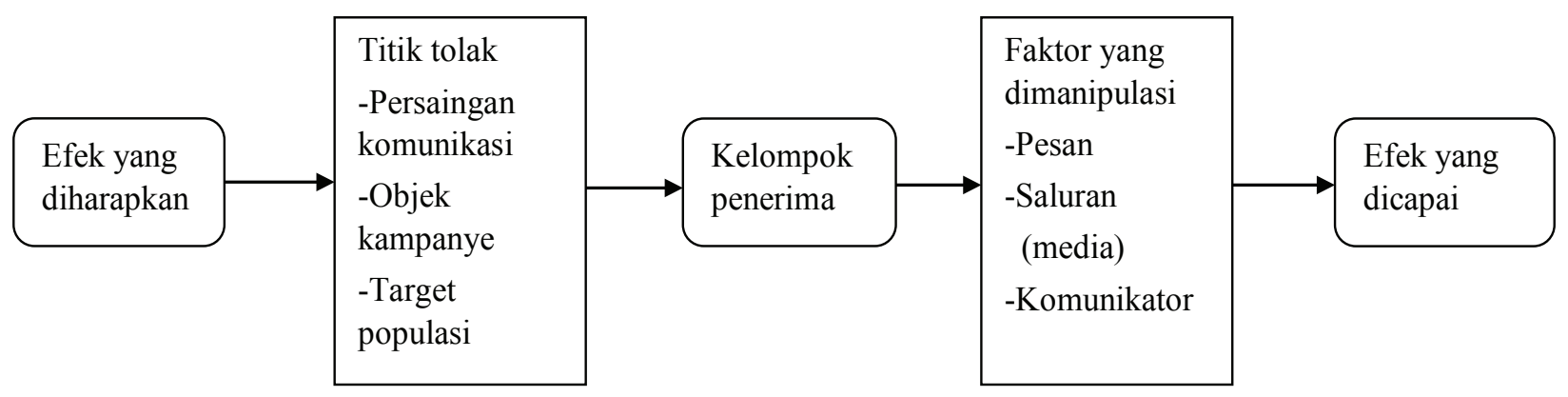

Bagan Model Kampanye Nowak dan Warneryd

Sumber: Manajemen Kampanye (Venus, 2012: 22) 
oleh relasi sosial produksi dan konsumsi kaum kapitalis; (4) Bahasa merupakan pembentukan subjektivitas (kesadaran sadar dan kesadaran tak sadar); (5) Kelompok-kelompok tertentu dalam suatu masyarakat mana pun memiliki hakhak istimewa di kelompok lain, dan meskipun alasan-alasan pemberian hak istimewa ini bisa saja sangat bervariasi, namun penindasan yang menjadi karakteristik masyarakat kontemporer sangat besar kemungkinannya berulang ketika subordinat (pihak tertindas) menerima status sosial mereka sebagai hal yang alami, perlu, atau tidak dapat dielakkan; (6) Penindasan memiliki banyak wajah dan memfokuskan diri hanya satu wajah dengan mengorbankan yang lain sering kali menghilangkan interkoneksi di antara mereka; dan (7) Praktik-praktik penelitian mainstream pada umumnya, meskipun kebanyakan sering kali tanpa disadari, berimplikasi terhadap reproduksi sistem penindasan kelas, ras dan gender (Denzin dan Lincoln, 2009: 173).

Dalam bahasa yang lebih sederhana, peneliti mengambil kesimpulan bahwa paradigma kritis menganggap bahwa terjadi kesenjangan dalam masyarakat, mulai dari kebijakan-kebijakan yang ada di dalamnya (adanya kebijakan berasal dari keputusan yang dibuat oleh kelompok superordinat yang memiliki kekuasaan); kehadiran kelompok-kelompok tertentu yang disertai dengan adanya 'hak istimewa tertentu'; hal yang dianggap fakta pun ternyata tak mampu berdiri secara mandiri (lepas dari ikatan ideologi tertentu) sampai pada penggunaan bahasa yang ada dalam masyarakat.

Metode penelitian ini ialah kualitatif dengan jenis penelitian studi kasus. "A case study is an exploration of a 'bounded system'or a case (or a multiple cases) overtime through detailed, indepth data collection involving multiple sources of information rich in context" (Creswell, 1998: 61). Dari pemahaman ini dapat dikatakan bahwa studi kasus ialah sebuah eksplorasi dari waktu ke waktu atas sebuah sistem yang terikat atau suatu kasus/beragam kasus yang dilakukan melalui pengumpulan data yang mendalam serta melibatkan berbagai sumber informasi yang kaya akan suatu konteks tertentu. Sistem ini terikat oleh waktu dan tempat, sedangkan kasus dapat dikaji dari suatu program, peristiwa, aktivitas, kelompok, organisasi atau pun seorang individu. Dapat disimpulkan pula bahwa studi kasus merupakan penelitian dimana peneliti menggali suatu fenomena tertentu dalam suatu kegiatan serta mengumpulkan informasi secara terperinci dan mendalam dengan menggunakan berbagai prosedur pengumpulan data selama periode tertentu.

Kasus yang menjadi dasar dan pokok penelitian ini ialah resistensi yang dilakukan oleh Komunitas Kretek. Adanya serangkaian tindakan komunikasi yang bersifat melawan, dilakukan komunitas ini merupakan upaya perjuangan akan pencegahan 'kepunahan' kretek dan tembakau di Indonesia. Saat sebagian besar masyarakat di Indonesia menyerukan kampanye anti rokok dan ingin menggilas keberadaan rokok dan tembakau (padahal sumbangan APBN dari sektor ini sangat banyak), Komunitas Kretek muncul dan memberikan wacana-wacana baru akan apa yang terjadi di balik kampanye-kampanye tersebut, baik melalui saluran gambar, poster, maupun penerbitan buku. Resistensi inilah yang akan diteliti secara mendalam menggunakan jenis metode studi.

\section{HASIL DAN PEMBAHASAN}

Berdasarkan tujuan penelitian yang ada, didapati hasil penelitianyang mengungkapkan bahwa Komunitas Kretek melakukan beberapa tindakan sebagai bentuk perlawanannya. Pertama, Komunitas Kretek melakukan perlawanan terhadap ratifikasi FCTC.

Hal pertama yang dilakukan Komunitas Kretek dalam melakukan resistensi untuk mempertahankan kemerdekaan kretek ialah dengan melawan terjadinya ratifikasi FCTC. Ratifikasi FCTC yang dianggap sebagai isu yang sangat hangat di Indonesia jika diberlakukan maka ada banyak faktor yang akan mengalami kerugian, mulai dari industri kretek sebagai produsen, serta para petani tembakau, petani cengkeh, buruh linting dan pedagang asongan yang terlibat dalam industri tersebut. Pembatasan jumlah produksi dan dilakukannya standarisasi produk tembakau dapat mengancam keberlangsungan industri rokok rumahan tak mampu melakukannya, bahkan telah banyak yang gulung tikar. Hasil panen para petani tembakau dan petani cengkeh tidak dapat diserap secara maksimal oleh industri kretek nasional karena diberlakukannya pembatasan tersebut, bahkan kalah bersaing dengan tembakau impor yang sedang gandrung dikirim 
ke Indonesia. Buruh linting pun terancam kehilangan lapangan pekerjaan karena jika diberlakukannya pembatasan dan standarisasi, maka produk tembakau akan banyak dilakukan oleh mesin (Sigaret Kretek Mesin) dan tidak lagi dilakukan secara manual oleh tangan-tangan buruh linting (Sigaret Kretek Tangan). Belum lagi jika menyinggung soal buruh panggul, para perajang tembakau dan pencacah cengkeh. Nilai lapangan pekerjaan yang disediakan oleh sektor kretek masih belum dapat digantikan dengan usaha bidang lainnya. Pemerintah sebagai pemegang kebijakan tertinggi di Indonesia juga akan mengalami kerugian. Diketahui bahwa pemasukan pendapatan negara paling besar berasal dari cukai rokok dan jika FCTC diberlakukan maka pemasukan tersebut akan berkurang, sedangkan dari sektor lainnya tidak ada yang mampu menyamai angka nominal jumlah pajak yang disumbangkan untuk pendapatan negara. Para pengkretek sebagai konsumen pun turut mengalami kerugian. Selain pembatasan produksi, pembatasan ruang gerak merokok pun gencar dilakukan. Banyaknya Kawasan Tanpa Rokok yang tidak diimbangi dengan tersedianya Ruang Boleh Merokok membuat para perokok dan pengkretek tidak bisa melakukan aktivitas merokoknya dengan nyaman.

Perlawanan Komunitas Kretek terhadap ratifikasi FCTC pertama kali dimulai dengan penggugatan kebijakan UU tentang Kesehatan tahun 2009 kepada pemerintah serta melakukan aksi protes di jalan; melakukan sosialisasi kepada para petani tembakau dan perekrutan jaringan yang lebih besar melalui koalisi yang terbentuk, serta melakukan penyebaran wacana kepada masyarakat lewat publikasi artikel, video Mat Kretek, kultwit di jejaring sosial Twitter, gambar-gambar bernada perlawanan, penerbitan buku Membunuh Indonesia, serta penyebaran pamflet, selebaran, stiker yang dilakukan saat beraksi di jalan.

Kedua, Komunitas Kretek mempertahankan hak-hak pengkretek.Sebagai komunitas yang berbasis pada kepentingan konsumen, Komunitas Kretek tak lupa untuk memperhatikan kepentingan konsumen. Tidak hanya melakukan perlawanan terhadap ratifikasi FCTC, namun Komunitas Kretek juga melindungi hak-hak pengkretek yang telah banyak diberangus oleh regulasi yang diberlakukan. Para pengkretek mengalami diskriminasi, baik dalam hal mengakses kawasan boleh merokok, perolehan beasiswa, perolehan lapangan pekerjaan, terancam tidak mendapatkan layanan Jamkesmas dan juga diharuskan untuk membayar pajak ganda, sampai terdapat seruan untuk tidak memilih caleg yang merokok. Melihat terjadinya diskriminasi ini, Komunitas Kretek melakukan berbagai upaya untuk tetap menjadikan para pengkretek memiliki hak yang sama dengan masyarakat Indonesia lainnya. Beberapa upaya yang dilakukannya yakni melakukan gugatan kebijakan kepada pemerintah tentang UU Kesehatan tahun 2009 mengenai Kawasan Tanpa Rokok yang berhasil berubah sesuai dengan gugatan yang diajukan oleh Komunitas Kretek; membuka kanal pengaduan diskriminasi perokok; serta melakukan survei tandingan mengenai Kawasan Boleh Merokok di 12 kota besar di Indonesia yang berujung pada ditampungnya apresiasi masyarakat mengenai aspek-aspek yang menjadi indikator kawasan tersebut disebut sebagai Kawasan Boleh Merokok yang nyaman.

Ketiga, Komunitas Kretek mempertahankan kretek sebagai cagar budaya Indonesia.Hal terakhir yang dilakukan Komunitas Kretek dalam mempertahankan kemerdekaan kretek ialah dengan menjadikan dan mempertahankan kretek sebagai cagar budaya Indonesia. Eksistensi kretek di Indonesia tak hanya bernilai ekonomi tinggi, namun sarat akan unsur budaya dan sejarah bangsa.

Usaha terakhir Komunitas Kretek ini menekankan bahwa sekalipun masyarakat Indonesia tidak semuanya merokok dan suka terhadap produk rokok, namun bukan berarti kretek sebagai produk asli Indonesia dapat dibiarkan 'musnah'karena kampanye-kampanye anti rokok serta regulasi dan kebijakan yang ada. Unsur budaya yang kuat yang terdapat dalam kretek inilah yang dijadikan argumen oleh Komunitas Kretek untuk tetap mempertahankan kretek sebagai salah satu cagar budaya yang ada, setelah sebelumnya banyak kebudayaan dan olahan asli Indonesia yang dicaplok hak miliknya oleh bangsa lain. Untuk itu Komunitas Kretek melakukan upaya penyebaran wacana kretek sebagai salah satu cagar budaya bangsa melalui publikasi artikel, forum, video Mat Kretek, resensi film dokumenter "Mereka yang Melampaui Waktu", gambar-gambar kretek yang bertema kebudayaan; mengadakan 
lomba nyethe serta menjadikan 3 Oktober sebagai Hari Kretek Nasional. Dilakukannya hal ini oleh Komunitas Kretek agar referensi masyarakat Indonesia akan pentingnya kretek bagi kebudayaan lokal Indonesia semakin kuat.

\section{SIMPULAN}

Komunitas Kretek melakukan resistensi untuk mempertahankan kemerdekaan kretek di Indonesia dengan melawan ratifikasi FCTC, merubah kebijakan yang dapat berakibat buruk terhadap keberlangsungan kretek di Indonesia, serta mempertahankan eksistensi kretek sebagai cagar budaya Indonesia.

Resistensi yang dilakukan Komunitas Kretek selama hampir 4 tahun ini bukanlah merupakan hal yang pendek. Berhasil digagalkannya beberapa kebijakan merupakan suatu prestasi tersendiri, namun jalan untuk berjuang di depan masih panjang. Penulis harapkan dalam pergerakannya ke depan tetap dibarengi dengan publikasi wacana-wacana yang lebih kritis, bahkan jika memungkinkan menerbitkan jurnal sehingga dapat diakses dan dijadikan bahan argumentasi yang kuat, baik bagi Komunitas Kretek maupun bagi para masyarakat pembacanya. Keterbaruan berita pun layak menjadi perhatian. Baik dalam pembuatan video, artikel, tema-tema di forum. Dilakukannya penelitian secara berkala dengan tema yang saling berhubungan dengan penelitian sebelumnya, serta penerbitan buku dengan tema yang masih bersinggungan dengan kretek juga dapat menambah bobot resistensi yang ada.

\section{DAFTAR PUSTAKA}

Creswell, J. W. (1998). Qualitative inquiry and research design: choosing among five traditions. California: Sage Publications.

Denzin, N. \& Lincoln, Y. (2009). Handbook of qualitative research. Yogyakarta: Pustaka Pelajar.

Norris, C. (2008). Membongkar teori dekonstruksi jacques derrida. Yogyakarta: Ar-Ruzz Media.

Ritzer, G. \& Goodman, D. J. (2005). Teori sosiologi modern. Jakarta: Prenada Media.

Venus, A. (2012). Manajemen kampanye. Bandung: Simbiosa Reakatama Media.

West, R. \& Turner, L.(2008). Pengantar teori komunikasi: analisis dan aplikasi. Jakarta: Penerbit Salemba Humanika.

Vinthagen, S. (2007). Understanding "Resistance": exploring definitions, perspectives, forms and implications. E-journal. School of Global Studies. Gothenburg University. 